\title{
STUDI KOMPARATIF KHAT NASKHI ABDURRAZIQ MUHAMMAD SALIM DAN MAHDI SAYYID MAHMUD
}

oleh:

\author{
Eko Prasetyo dan Maman Abdul Jalil \\ UIN Sunan Gunung Djati \\ Prasetyoase.o@gmail.com
}

\begin{abstract}
Dalam perkembangannya kaligrafi memiliki beberapa jenis tulisan, yang terdiri dari Al-Aqlam Al-Sittah (kaligrafi enam), yang meliputi: khat Naskhi, Tsuluts, Muhaqqaq, Raihani, Riqa'dan Tauqi'. Adapun dalam penggunaannya, khat Naskhi cenderung lebih banyak digunakan dalam berbagai media tulisan, baik itu berupa tulisan tangan maupun yang berbasis digital. Khat Naskhi dengan penulisan tangan pun memiliki beberapa perbedaan antar tokoh, baik itu dalam cara penulisan maupun bentuk yang dihasilkan dari proses penulisannya. Tokoh yang menjadi fokus dalam penelitian ini yaitu Abdurraziq Muhammad Salim serta Mahdi Sayyid Mahmud. Keduanya memiliki perbedaan satu sama lain dari cara penulisan serta bentuk yang dihasilkan dari penulisan tersebut. Adapun dalam proses penelitian ini digunakan metode komparatif sebagai alat bantu mrnganalisis bentuk serta cara penulisan, serta teori tipografi dalam menganalisis tulisan kedua tokoh tersebut.

Metode komparatif merupakan metode yang mempelajari data-data dari satu atau beberapa objek kajian, Data-data dari beberapa variabel tersebut diperbandingkan secara cermat untuk memperoleh kaidah-kaidah perubahan yang terjadi dalam variabel itu. serta teori tipografi yaitu teori yang berlandaskan pada teori gestalt yang membahas anatomi serta faktorfaktor yang menjadi kaitannya dengan huruf. Dengan hal ini penulis mensinkronkan antara teori dengan bahan yang akan di kaji, setelah itu ditemukan beberapa hasil bahwa dengan menggunakan teori serta metode komparatif, kedua tokoh memiliki banyak sekali perbedaan, baik dalam cara penulisan maupun dalam bentuk yang dihasilkan dari cara penulisan tersebut. Untuk lebih terperinci dapat dilihat dari lembar selanjutnya peneitian ini. Tentunya dengan adanya hasil dari pada penelitian ini, mudahmudahan dapat bermanfaat bagi penulis, umumnya teruntuk khalayak umum
\end{abstract}

\section{KEYWORDS:}

khat naskhi, perbandingan, anatomi huruf 


\section{PENDAHULUAN}

Perkembangan kaligrafi dalam Islam sejak awal menunjukan kedekatannya dengan AI-Qur'an. Pesan yang dibawa kaligrafi adalah pesan Al-Qur'an itu sendiri. Bahkan Al-Qur'an ditulis dengan tulisan kaligrafi elok dengan ukiran emas. Sebagai sebuah 'pembawa pesan' kaligrafi tentu saja mempunyai kedudukan istimewa di antara cabang-cabang seni islam yang lain. Sebagaimana yang dikatakan oleh syaikh Syamsuddin Al-Akfani dalam kitabnya :

"kaligrafi adalah suatu ilmu yang memperkenalkan bentuk bentuk huruf tunggal, letak-letaknya, dan tata cara merangkainya menjadi sebuah tulisan yang tersusun atau apa yang ditulis di atas ganis-garis, bagaimana cara menulisnya dan menentukan mana yang tidak perlu ditulis, menggubah ejaan yang perlu di ubah dan menentukan cara bagaimana untuk menggubahnya." (Al-Akfani, 1994: 3-4)

Dalam bahasa Arab kaligrafi disebut dengan Fann Al-Khatt (seni tulis). Kata khat dapat diartikan dengan garis atau tulisan. Orang yang ahli dalam menulis halus disebut Al-Khath Thaath (Chaligrapher) (Makin, 1995: 8). Kaligrafi dalam arti The art of penmanship memang benar. Karena kecakapan menulis halus "sebenarnya" merupakan kecakapan pena dalam menulis. Muhammad Thahir Abd al-Qodir al-Kurdi dalam karyanya pernah mengumpulkan sekitar tujuh macam pengenalan kaligrafi atau Khat dan kemudian menyimpulkan bahwa yang dimaksud dengan kaligrafi adalah:

"suatu kepandaian untuk mengatur gerakan ujung-ujung jari dengan memanfaatkan pena dalam tata cara tertentu. Yang dimaksud dengan "pena" disini adalah gerakan ujung-ujung jari, sementara "tata cara tertentu" merujuk pada semua jenis kaidah-kaidah penulisan." (Qadir, 1982: 23)

Berbeda halnya dengan pendapat Ya'qut al-Musta'simi yang merupakan seorang kaligrafer kenamaan di masa kesulatanan Turki Usmani (Ottoman) yang melihat seni kaligrafi dari sudut keindahan rasa yang dikandungnya. Karena itu, in membuat batasan bahwa: 


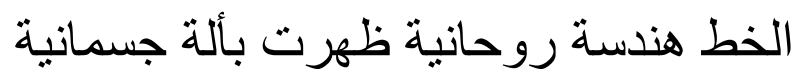

"Kaligrafi adalah seni geometri rohaniah, yang dilahirkan melalui alat-alat jasmaniah.” (Asy-Syaqqaqi, 1987: 225)

Pendapat lain juga dikemukakan oleh Didin Sirojuddin bahwa kaligrafi adalah unsur ornamen terpenting bagi seniman Muslim karena banyak digunakan untuk mengolah ayat-ayat Al-Qur'an yang menjadi pegangan utama hidupnya. (Sirojuddin, 1992: 3)

Dari beberapa pengertian di atas, dapat disimpulkan bahwa kaligrafi adalah suatu tulisan indah huruf-huruf tertentu yang memiliki disiplin atau kaidah dalam penulisannya (Makin, 1995: 10). Adapun Tokoh yang menjadi fokus dalam penelitian ini yaitu Abdurraziq Muhammad Salim serta Mahdi Sayyid Mahmud.

Abdurraziq Muhammad Salim lahir di Mesir pada 12 Mei 1908, ia merupakan Inspektor dan pengarah kaligrafi mesir sehingga semakin berkembang. Semasa menempuh pendidikan, beliau mengajar di Madrasah Al-Khatt Al-Araby yang lulus pada tahun 1932, pada tahun 1932 beliau masih berstatus sebagai mahasiswa universitas Daarul Ulum. Kemudian beliau meraih gelar diploma pada tahun 1943 dengan spesialisasi kaligrafi dan seni ornament dan mengajar di Wuzaroh Al-Maarif Al-Mishriyyah (kementrian pendidikan Mesir) sebagai pengajar Kaligrafi. Kemudian ditunjuk menjadi guru Kaligrafi di Madrasah Tahsin Al-Khutut Al-Arobiyah Kairo. la dikenal sebagai seorang yang ahli dalam Khat Tsuluts dan Farisi serta dikenal dengan seorang yang dapat menandingi kehebatan kaligarfer Iran yang memang jagonya dalam Khat Farisi (Sayyed, 54). Kemudian tokoh kedua yan menjadi fokus dalam penelitian ini adalah Mahdi Sayyid Mahmud.

Mahdi Sayyid Mahmud dilahirkan di kota Kairo, Mesir. Beliau merupakan salah satu seorang pelopor dalam bidang seni Kaligrafi Arab modern. Kemahirannya dalam bidang seni serta kaligrafi sudah menjadi 
bakatnya sejak kecil. Ketika ia kecil, beliau masuk ke sekolah Tahsinul Khuttut Al Malakiyyah yang kemudian mendapat gelar diploma pada tahun 1935. Pada tahun 1965, beliau belajar kepada master Mahmud Ali Al Makawy di Madrasah Tahsinul Khuttut, disana beliau diangap sebagai murid kesayangan, hingga sang guru pernah berkata "Mahmud engkau adalah anakku". Hal itu diungkapkan sang guru, karena Mahmud telah mampu belajar dengan baik dan sungguh -sungguh serta menyempunakan khat Naskhi dan Tsuluts yang diajarkannya. Setelah cukup dalam berbagai gaya penulisan kaligrafi oleh gurunya Syaikh Mahmud Ali Al Makawy, beliau melanjutkan rihlah pembelajaran kaligrafinya kepada Ghazalan Bik, untuk mempelajari khat lainnya. Kemudian belajat khat Kufi kepada Yusuf Ahmad, dan Farisi kepada Husni dan Hawawiny, sedangkan Khat Riq'ah belajar dari Muhammad Abdurrahman dan Muhammad Gharib Al Quraby. Beliau menikah pada tahun 1945, yang kemudian dikaruniai 5 anak. Diantara lima anaknya itu, dua diantaranya telah memperoleh diploma Al Khuttut, dan salah satu diantara mereka ada yang bekerja di Arab sebagai pembuat Kaligrafi.

Hampir sebagian usianya di berikan untuk mempelajari ilmu Khat serta menyampaikannya kembali. la mengajar di beberapa Madrasah yang terdapat di Mesir. Adapun karya-karya berupa buku yang ia tulis seperti 'Allim Nafsaka Al-Khutut Al-Arobiyyah naskhi, 'Allim Nafsaka Al-Khutut AlArobiyyah Riq'ah, 'Allim Nafsaka Al-Khutut Al-Arobiyyah Farisi, 'Allim Nafsaka Al-Khutut Al-Arobiyyah Tsuluts serta 'Allim Nafsaka Al-Khutut AlArobiyyah Diwani.

Dalam penelitian penulis mencoba menganalisis persamaan dan perbedaan dalam bentuk serta cara penulisan kedua tokoh menggunakan metode Komparatif. Di samping itu, penulis juga menggunakan teori kaligrafi Arab serta teori Tipografi. Yang mana tipografi sendiri pada praktisnya merupakan sebuah kajian ilmu yang membahas serta mendalami sebuah huruf . seperti halnya tubuh manusia, huruf memiliki berbagai organ yang 
berbeda. Gabungan seluruh elemen dari sebuah bentuk huruf merupakan identitas visual yang dapat membedakan antara huruf yang satu dengan yang lainnya. (Danton, 2001: 128)

\section{LANDASAN TEORITIS DAN METODE}

Sebagai mana tubuh manusia, huruf memiki berbagai organ tubuh yang berbeda. Gabungan dari semua elemen dari sebuah bentuk huruf merupakan identitas visual yang dapat membedakan antara huruf yang datu dengan huruf yang lainnya (Danton, 2001: 128). Huruf juga merupakan salah satu perwakilan rupa dari komunikasi verbal. Bentuk huruf yang dicipta bukan hanya berfungsi sebagai simbol bunyi, namun juga dapat menghasilkan intepretasi terhadap sebuah makna dan ekspresi. Sebagaiman huruf-huruf lainnya, huruf arab pun memiliki berbagai keunikan tersendiri baik itu dari beberapa aspek. walaupun perkembangan huruf arab memang tidak bgitu pesat dalam perkembangannya dibanding huruf latin, namun tentu saja huruf arab tetap memiliki tempat tersendiri dalam penggunaannya. Menurut Edward said alam jurnalnya yang berjudul Orientalism: Western Conseptions of the Orient, ia mengatakan:

"selama abad 19 hinggan abad 21 telah menjadi sebuah asumsi umum bahwa belahan Timur serta berbagai isinya secara nyata kalah dari belahan Barat, maka dari itu dibutuhkan studi korektif oleh belahan Barat."

Dengan adanya visi di atas, diharapkan agar perbedaan antara keilmuan Barat serta keunikan Timur dapat saling bertukar melalui interaksi diantara keduanya dalam berbagai bidang keilmuan, khususnya sistem penulisan. (Sherry, 2003: 60)

Bila dilihat dari penjelasan yang diungkapkan oleh Edward memang ada benarnya karena dalam perkembangannya, keilmuan Barat dewasa ini lebih pesat dari Timur. Namun bila dilihat dari sisi lainnya, wilayah Timur memiliki keunikan seni serta keunikan yang tidak dimiliki Barat pada umumnya. Dalam hal ini ilmu tentang huruf yang penggunaannya masih terbatas pada huruf huruf latin. Namun dengan adanya studi yang mencoba menyatukan studi Barat dengan keunikan dari pada wilayah Timur 
berdampak pada terciptanya keselarasan dalam bidang keilmuan serta bertambahnya ilmu-ilmu baru yang sebelumnya belum tercipta. Lebih khususnya lagi ilmu tentang huruf, yaitu Tipografi yang sebelumnya hanya dipakai untuk mengkaji huruf-huruf latin, namun dewasa ini dapat digunakan dalam huruf-huruf arab. Menurut Huda Abi Fares dalam jurnalnya yang berjudul Arabic Typography: A Comprehensif Sourse Book, ia mengatakan:

"pada hakikatnya Tipografi huruf latin dan huruf arab tidak dapat disandingkan, baik itu dari bagian atas, bagian bawah, ataupun hubungan lainnya. namun beberapa ahli telah menemukan cara untuk memilih Tipografi sehingga dapat dipakai baik itu dalam hal komposisi serta gaya, sehingga kedua bentuk penulisan kedua bahasa itu tampak kompatibel. Para ahli telah mengkonfigurasi tata letak, sehingga suatu bahasa mampu serta mempungkinkan beroprasi secara terpisah namun pada sandingan yang tepat. Hal ini membuktikan bahwa Tipografi non latin mampu di jalankan dalam kaligrafi Arab." (Sherry, 2003: 60)

Dari penjelasan diatas dapat diambil kesimpulan bahwa Tipografi sekarang ini dapat digunakan dalam mengkaji huruf arab. Hal itu telah dibuktikan dengan berbagai litelatur serta berbagai jurnal yang terkait dengan Tipografi huruf arab. Sebagaimana fungsinya Tipografi mengedepankan olah huruf bukan sekedar hanya untuk dibaca namun juga sebagai sebuah gambar, simbol, dan ekspresi dari pada penulisnya.

Seorang peneliti dalam penelitiannya selain membutuhkan objek kajian, juga membutuhkan metode serta pendekatan penelitian yang memadai untuk melakukan penelitiannya. Adapun dalam penelitian Skripsi ini penulis mengunakan "Pendektan kualitatif" yang berdasarkan pada penelitian kepustakaan (library research). Penelitian ini disebut dengan penelitian kualitatif karena penelitian ini menghasilkan data-data yang berupa kata-kata tertulis dari berbagai sumber yang di jadikan objek kajian. Penelitian kualitatif juga dijelaskan oleh Lexy J Moleong (2000: 11) yang mengatakan bahwa "Penelitian kualitatif sebagai prosedur penelitian yang menghasilkan data diskriptif berupa kata-kata tertulis atau lisan dari orangorang dan perilaku yang dapat diamati”. yang mana pengumpulan bahanbahan perpustukaan akan dijadikan sumber utama sebagai fokus penelitian 
pembahasan skripsi ini. Adupun sumber data diperoleh dari buku-buku, jurnal-jurnal yang relevan dengan pokok permasalahan, melalui metode dokumentasi.

Metodologi adalah cara yang teratur dan terpikir baik-baik untuk mencapai maksud (dalam ilmu pengetahuan, dsb) cara kerja yang bersistem untuk memudahkan pelaksanaan suatu kegiatan untuk mencapai tujuan yang ditentukan. Adapun metodologi atau metode harus dipertimbangkan dalam 2 segi; yang pertama yaitu segi penelitian itu sendiri yang mencakup pengumpulan data beserta cara, dan teknis serta prosedur yang ditempuh, segi lain yaitu metode kajian (Analisis) yang melibatkan pendekatan (Teori) sebagai alat analisis data penelitian. (Djajasudarma, 1993: 1)

Menurut Sugiono (2014: 2) dalam bukunya mengatakan bahwa secara umum metode penelitian diatikan sebagai cara ilmiah untuk mendapatkan data dengan tujuan dan kegunaan tertentu. Beliau juga berpendapat bahwa suatu penelitian dilakukan untuk mengetahui keberadaaan suatu variabel, baik itu variabel mandiri maupun beberapa variabel. (Sugiono, 2014: 53)

Setelah data terkumpul, proses penyusunan skripsi ini menggunakan "metode deskriptif-analitis". Deskriptif, yakni memberikan gambaran terhadap data yang ada berikut penjelasan-penjelasan. Penelitian dibahasakan menurut kekhususan dan kekonkretannya sehingga menjadi terbuka bagi pemahaman umum. Kemudian bersifat analisis karena penulis melakukan pemeriksaan dan pengkajian secara konseptual atas makna yang dikandung oleh istilah-istilah yang digunakan. (Soemargono, 1986: 18)

Selain itu, penulis menggunakan "metode komparasi" untuk mencari Persamaan dan perbedaan dalam memperbandingkan kedua tokoh tersebut dan analisa induksi-deduksi untuk sintesis pemikiran, meliputi semua unsur secara seimbang, untuk memahami lebih detail terhadap pemikiran tokoh tersebut. Dalam penelitian ini, penulis menggunakan komparasi simetris, yakni Perbandingan dapat dibuat setelah masing- 
masing pandangan diuraikan secara lengkap. Harus dibedakan juga taraf mana yang dibandingkan. Apakah taraf yang tampak dan konkret ataukah taraf yang lebih mendalam, sampai pada dasar dan asumsi-asumsi yang paling dasar. (Anton, 1990:87)

Jadi dapat diambil kesimpulan bahwa penelitian komparatif adalah jenis penelitian yang digunakan untuk mempelajari data-data dari satu atau beberapa objek kajian, Data-data dari beberapa variabel tersebut diperbandingkan secara cermat untuk memperoleh kaidah-kaidah perubahan yang terjadi dalam variabel itu. (Anton, 1990:87)

\section{HASIL DAN PEMBAHASAN}

Berdasarkan pemaparan diatas, dapat diketahui bahwa penggunaan Tipografi sekarang ini dapat digunakan dalam mengkaji huruf arab. Hal itu telah dibuktikan dengan berbagai litelatur serta berbagai jurnal yang terkait dengan Tipografi huruf arab. Sebagaimana fungsinya Tipografi mengedepankan olah huruf bukan sekedar hanya untuk dibaca namun juga sebagai sebuah gambar, simbol, dan ekspresi dari pada penulisnya.

Selain itu, penulis menggunakan "metode komparasi" untuk mencari Persamaan dan perbedaan dalam memperbandingkan kedua tokoh tersebut dan analisa induksi-deduksi untuk sintesis pemikiran, meliputi semua unsur secara seimbang, untuk memahami lebih detail terhadap pemikiran tokoh tersebut. Dalam penelitian ini, penulis menggunakan komparasi simetris, yakni Perbandingan dapat dibuat setelah masingmasing pandangan diuraikan secara lengkap. Harus dibedakan juga taraf mana yang dibandingkan. Apakah taraf yang tampak dan konkret ataukah taraf yang lebih mendalam, sampai pada dasar dan asumsi-asumsi yang paling dasar. (Anton, 1990:87)

Jadi dapat diambil kesimpulan bahwa penelitian komparatif adalah jenis penelitian yang digunakan untuk mempelajari data-data dari satu atau beberapa objek kajian, Data-data dari beberapa variabel tersebut 
diperbandingkan secara cermat untuk memperoleh kaidah-kaidah perubahan yang terjadi dalam variabel itu. (Anton, 1990:87)

Adapun data yang dimaksud adalah buku kaligrafi Abdurraziq Muhammad Salim dan Mahdi Sayyid Mahmud. Penelitian ini dilakukan untuk menemukan persamaan dan perbedaan masalah yang dikaji, yang kemudian setelah dikaji dilakukanlah perbandingan, sehingga dapat di identifikasi persamaan dan pebedaan kedua tokoh dalam penulisan serta bentuk yang dihasilkan kedua tokoh.

Setelah membaca dan mencermati cara penulisan dan bentuk yang terdapat dalam buku Al-Haadii Fii ta'lim khattin Naskhi karya Abdurraziq Muhammad Salim dan buku 'Allim Nafsaka Al-Khutuut Al-Arabiyyah karya Mahdi sayyid Mahmud penulis menemukan beberapa persamaan dan perbedaan dalam penulisan dan bentuk kedua tokoh. Yang dapat di gambarkan sebagai berikut:

Alif dalam buku Abdurraziq Muhammad Salim yang berjudul AlHaadii Fii ta'lim khattin Naskhi

1. Huruf alif tunggal

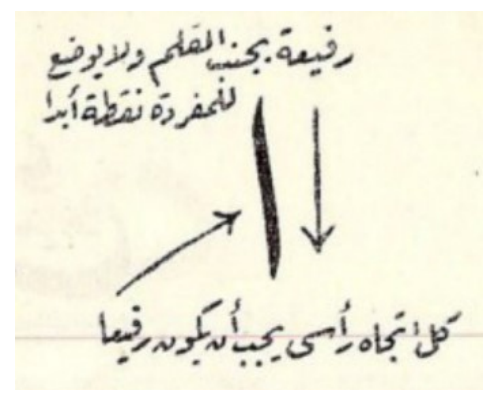

Adapun cara penulisan alif tunggal menurut Mahdi Sayyid Mahmud yaitu dapat dilihat diketerangan atas sebagai berikut :

Cara/Gaya penulisan yaitu dengan ngangkat pena dalam keadaan berbaring (maksudnya mata pena berada dalam posisi Vertikal), dan tidak boleh selamanya meletakkan nuqtah (titik) pada alif mufrad (sendiri). Kemudian semua arah vertikal harus ditulis dari atas. 
Bentuk, dengan langkah langkah penulisan seperti di atas dihasilkan:

1. Baseline : memiliki posisi rujukan dari setiap huruf Arab baik itu dari huruf ب sampai huruf

2. Cap height/meanline : memiliki posisi rujukan dari huruf $b, b$, J, ע

3. X-Height : memiliki tinggi lima titik (Nuqtah)

4. Ascender : huruf alif tidak memiliki bagian ini

5. Descender : huruf alif tidak memiliki bagian ini

6. Apex : huruf alif ini memiliki bentuk yang lancip di sebelah kanan atas dan membentuk sudut $70-80$ derajat.

7. Bar : huruf alif tidak memiliki bagian ini

8. Stem : Huruf alif ini memiliki ukuran dari setengah titik (Nuqtah)

9. Serif : dalam huruf ini bagian alif memiliki bentuk yang lancip di sebelah bawah kiri dengan membentuk sudut 75-85 derajat.

10. Bracket : Huruf alif tidak memiliki bagian ini

11. Link : Huruf alif tidak memiliki bagian ini

12. Bowl : Huruf alif tidak memiliki bagian ini

13. Loop : Huruf alif tidak memiliki bagian ini

14. Shoulder : Huruf alif tidak memiliki bagian ini

15. Terminal : Huruf alif tidak memiliki bagian ini

16. Eye : Huruf alif tidak memiliki bagian ini

17. Counter: Huruf alif tidak memiliki bagian ini

18. Form : Huruf alif tidak memiliki bagian ini

19. Open counter: Huruf alif tidak memiliki bagian ini

20. Tail : Huruf alif tidak memiliki bagian ini

21. Imbangan : menghasilkan bentuk huruf yang tebal

22. Irama dan Harmoni : irama dalam tulisan tersebut halus dalam goresannya namun tetap memperhatikan harmoni tulisan yang konsisiten. 
2. Huruf alif sambung

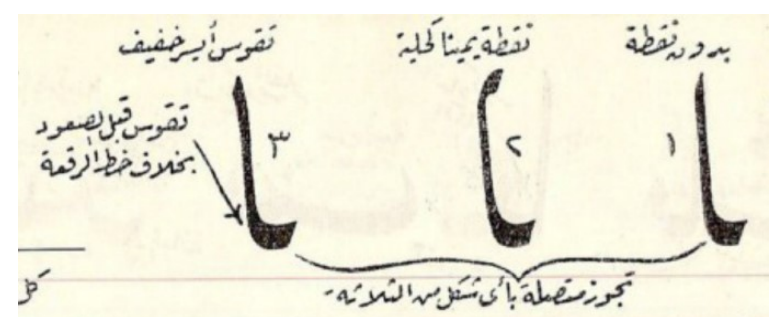

Terdapat 3 cara penulisan dan 3 bentuk yang digunakan oleh Abdurraziq Muhammad Salim yaitu:

Cara penulisan. merujuk pada keterangan gambar di atas sebelah kiri yang maksudnya yaitu melenturkan goresan pena sebelum naiknya goresan dari bawah keatas karna berbeda dengan penulisan Khat Riq'ah yang penulisannya lebih kaku tanpa lenturan sehingga mempengaruhi bentuk akhir. Alif tanpa hiasan ini disebut dengan alif layyin.

Merujuk pada keterangan gambar di atas sebelah kiri yang maksudnya yaitu melenturkan goresan pena sebelum naiknya goresan dari bawah keatas karna berbeda dengan penulisan Khat Riq'ah yang penulisannya lebih kaku tanpa lenturan sehingga mempengaruhi bentuk akhir. Namun diakhir goresan adanya tambahan 'perhiasan' atau Nuqtah yang mengarah ke kanan.

Merujuk pada keterangan gambar di atas sebelah kiri yang maksudnya yaitu melenturkan goresan pena sebelum naiknya goresan dari bawah keatas karna berbeda dengan penulisan Khat Riq'ah yang penulisannya lebih kaku tanpa lenturan sehingga mempengaruhi bentuk akhir. Alif ini disebut juga dengan alif mail

Bentuk dalam bentuk terbagi menjadi:

1. Baseline : memiliki posisi rujukan dari setiap huruf Arab baik itu dari huruf ب sampai huruf .

2. Cap height/meanline : memiliki posisi rujukan dari huruf $b, b$, J, y

3. X-Height : memiliki tinggi lima titik (Nuqtah)

4. Ascender : huruf alif tidak memiliki bagian ini 
5. Descender : huruf alif tidak memiliki bagian ini

6. Apex : huruf alif ini memiliki bentuk yang lancip di sebelah kanan atas dan membentuk sudut $70-80$ derajat.

7. Bar : huruf alif tidak memiliki bagian ini

8. Stem : Huruf alif ini memiliki ukuran dari setengah titik (Nuqtah)

9. Serif : dalam huruf ini bagian alif memiliki bentuk yang lancip di sebelah bawah kiri dengan membentuk sudut 75-85 derajat.

10. Bracket : Huruf alif tidak memiliki bagian ini

11. Link : Huruf alif tidak memiliki bagian ini

12. Bowl : Huruf alif tidak memiliki bagian ini

13. Loop : Huruf alif tidak memiliki bagian ini

14. Shoulder: Huruf alif tidak memiliki bagian ini

15. Terminal : Huruf alif tidak memiliki bagian ini

16. Eye : Huruf alif tidak memiliki bagian ini

17. Counter: Huruf alif tidak memiliki bagian ini

18. Form : Huruf alif tidak memiliki bagian ini

19. Open counter : Huruf alif tidak memiliki bagian ini

20. Tail : Huruf alif tidak memiliki bagian ini

21. Imbangan : dalam ketiga tulisan alif sambung di atas menghasilkan bentuk huruf yang tebal kemudian menipis disebabkan konsistennya dalam pemegangan pena.

22. Irama dan Harmoni : irama dalam tulisan tersebut halus dalam goresannya tidak adanya lekukan tajam namun harmoninya tetap diperhatikan sehingga menghasilkan bentuk yang elok untuk dilihat.

Diperbolehkan dalam penulisan alif sambung dengan berbagai bentuk dari ketiga ini.

Kedua yaitu dalam buku 'Allim Nafsaka Al-Khutuut Al-Arabiyyah karya Mahdi sayyid Mahmud 
1. Alif tunggal

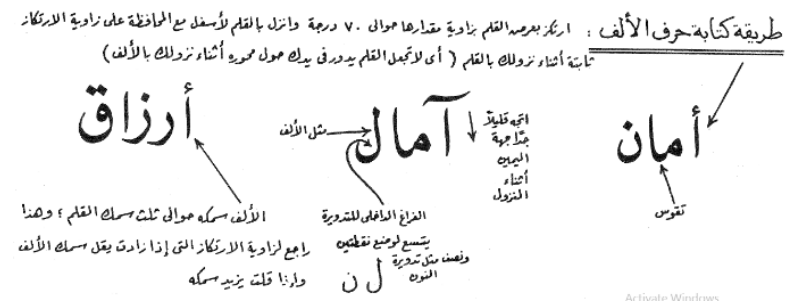

Cara penulisan. Fokus pada sebagian pena menyamping yang ukuran pena tersebut sekitar 70 derajat. Kemudian menurunkan pena kearah bawah dengan fokus dan hati-hati. Tetap berada pada jalur dalam menurunkan pena (yaitu tidak membuat pena berputar dalam genggaman tangan sehingga berpindahnya arah jalur dalam menurunkan goresan alif). Ukurannya berada pada 4 titik dan tebalnya sepertiga pena.

Bentuk. Dengan langkah langkah penulisan seperti di atas dihasilkan:

1. Baseline : memiliki posisi rujukan dari setiap huruf Arab baik itu dari huruf $ب$ sampai huruf

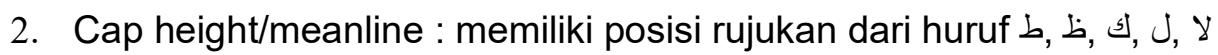

3. X-Height : memiliki tinggi lima titik (Nuqtah)

4. Ascender : huruf alif tidak memiliki bagian ini

5. Descender : huruf alif tidak memiliki bagian ini

6. Apex : huruf alif ini memiliki bentuk yang lancip di sebelah kanan atas dan membentuk sudut $70-80$ derajat.

7. Bar : huruf alif tidak memiliki bagian ini

8. Stem : Huruf alif ini memiliki ukuran dari setengah titik (Nuqtah)

9. Serif : dalam huruf ini bagian alif memiliki bentuk yang lancip di sebelah bawah kiri dengan membentuk sudut 75-85 derajat.

10. Bracket : Huruf alif tidak memiliki bagian ini

11. Link : Huruf alif tidak memiliki bagian ini

12. Bowl : Huruf alif tidak memiliki bagian ini

13. Loop : Huruf alif tidak memiliki bagian ini

14. Shoulder : Huruf alif tidak memiliki bagian ini 
15. Terminal : Huruf alif tidak memiliki bagian ini

16. Eye : Huruf alif tidak memiliki bagian ini

17. Counter: Huruf alif tidak memiliki bagian ini

18. Form : Huruf alif tidak memiliki bagian ini

19. Open counter : Huruf alif tidak memiliki bagian ini

20. Tail : Huruf alif tidak memiliki bagian ini

21. Imbangan : menghasilkan bentuk huruf yang tebal

22. Irama dan Harmoni : irama dalam tulisan tersebut halus dalam goresannya namun tetap memperhatikan harmoni tulisan yang konsisiten.

2. Huruf alif akhir

Adapun cara penulisan alif ini ada 2 yaitu di antaranya:

Cara penulisan. Merujuk pada keterangan gambar di atas sebelah kanan maksudnya yaitu melenturkan goresan pena sebelum naiknya goresan dari bawah keatas. Alif ini disebut juga dengan alif layyin.

Melenturkan pena secara ringan dengan adanya 'perhiasan' kearah kanan di ujung goresan, adapun cara penulisannya yaitu dengan tidak

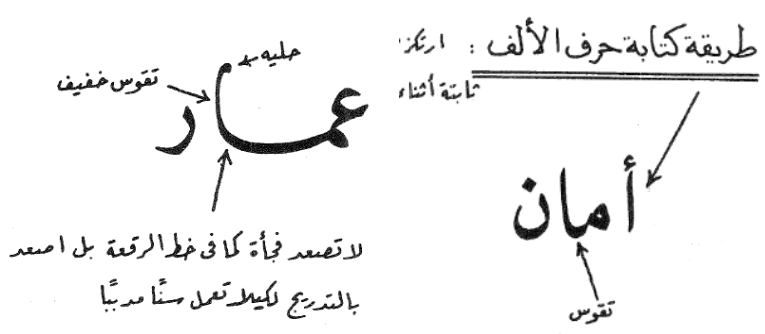

menaikkan tiba-tiba seperti khat riq'ah tetapi naikkan dengan perlahan supaya tidak terjadi goresan tajam pada bagian bawah goresan.

Bentuk. Bentuk terbagi menjadi: 
1. Baseline : memiliki posisi rujukan dari setiap huruf Arab baik itu dari huruf $ب$ sampai huruf $\mathrm{s}$

2. Cap height/meanline : memiliki posisi rujukan dari huruf $b, b$, J, y

3. X-Height : memiliki tinggi lima titik (Nuqtah)

4. Ascender : huruf alif tidak memiliki bagian ini

5. Descender : huruf alif tidak memiliki bagian ini

6. Apex : huruf alif ini memiliki bentuk yang lancip di sebelah kanan atas dan membentuk sudut 70-80 derajat.

7. Bar : huruf alif tidak memiliki bagian ini

8. Stem : Huruf alif ini memiliki ukuran dari setengah titik (Nuqtah)

9. Serif : dalam huruf ini bagian alif memiliki bentuk yang lancip di sebelah bawah kiri dengan membentuk sudut 75-85 derajat.

10. Bracket : Huruf alif tidak memiliki bagian ini

11. Link : Huruf alif tidak memiliki bagian ini

12. Bowl : Huruf alif tidak memiliki bagian ini

13. Loop : Huruf alif tidak memiliki bagian ini

14. Shoulder: Huruf alif tidak memiliki bagian ini

15. Terminal : Huruf alif tidak memiliki bagian ini

16. Eye : Huruf alif tidak memiliki bagian ini

17. Counter : Huruf alif tidak memiliki bagian ini

18. Form : Huruf alif tidak memiliki bagian ini

19. Open counter : Huruf alif tidak memiliki bagian ini

20. Tail : Huruf alif tidak memiliki bagian ini

21. Imbangan : dalam ketiga tulisan alif sambung di atas menghasilkan bentuk huruf yang tebal kemudian menipis disebabkan konsistennya dalam pemegangan pena.

22. Irama dan Harmoni : irama dalam tulisan tersebut halus dalam goresannya tidak adanya lekukan tajam namun harmoninya tetap diperhatikan sehingga menghasilkan bentuk yang elok untuk dilihat. 


\section{PENUTUP}

Sebagai mana contoh di atas, terdapat persamaan dan perbedaan dalam buku panduan belajar kaligrafi Al-Hadi fii ta'lim Khattin Naskhi karya Abdurraziq Muhammad Salim dengan buku 'Allim Nafsaka Al-Khutut AlArabiyyah karya Mahdi Sayyid Mahmud baik itu dari bermacam-macamnya bentuk tulisan, maupun dalam cara penulisannya.

\section{DAFTAR PUSTAKA}

Esa,Sulaeman. Dalam 'introduction' untuk Katalog Pameran School of Art and Design Institute of Technology Mara Shah Alam Malaysia. Malaysia, 23 Juni 1995

Gazalba,Sidi. Islam dan Kesenian, Relevansi Islam dengan Seni Budaya Karya Manusia. Jakarta: Pustaka Alhusna, 1998

Hidayat,subhan. Al- Khattat Abdurraziq Muhammad Salim diterj Abdurraziq Muhammad Salim, Sang Guru Besar Kaligrafi Mesir.

Ismail Al-Faruqi dan lamya Al-Faruqi. Atlas Budaya Islam terj Moh. Ridzuan Othman dkk. Malaysia: Dewan Bahasa dan Pustaka Kementrian Pendidikan, 1992

J.Pedersen. fajar Intelektualisme Islam terj Alwiyah Abdurrahman. Bandung: Mizan, 1999

Mahmud,Mahdi. 'Allim Nafsaka Al-Khutut Al-Arobiyyah Naskhi. Mesir. 1953

Naji Zainuddin Asy-Syaqqaqi, Mashawwar Al- Khatt Al- 'Araby,

Read,Derbert. The Meaning of Art yang diterj Pengertian Seni oleh Soedarso. Yogyakarta: Sekolah Tinggi Seni Rupa Indonesia, 1973

Salim,Abdurraziq. Al-Hadi Fii Ta'lim Khattatin Naskhi. Mesir. 1902

Sayyed Hossein Nasr, menjelajah Dunia Modern, Bimbingan untuk Kaum Muda Muslim terj Hasti Tarekat. Bandung: Mizan, 1994.

Shihab,Quraish. Wawasan Al-Qur'an. Bandung: Mizan, 1996

Sirojuddin,Didin. Khat Naskhi untuk kebutuhan Primer Baca Tulis. Jakarta.1993 